\title{
Pengaruh daur ulang litter terhadap kualitas litter dan udara dalam pemeliharaan broiler
}

\author{
Muhamad Najibulloh *, Niken Ulupi, Salundik \\ Program Studi Ilmu Produksi dan Teknologi Peternakan, Fakultas Peternakan, IPB University, Bogor, 16680 \\ *Correspondence: muhamadn55@gmail.com
}

Received: January 5th 2020 ; Accepted: March 5th 2020 ; Published online: July 17th 2020

\section{Abstrak}

Tujuan: Pada umumnya peternak mengunakan litter dari bahan sekam padi. Akan tetapi seiring dengan penurunan lahan persawahan, sekam padi sulit didapat dan harganya mahal. Salah satu upaya yang dapat dilakukan yaitu dengan menggunakan kembali litter yang telah digunakan. Tujuan dari penelitian ini adalah untuk menganalisis pengaruh daur ulang terhadap kualitas litter dan udara pada pemeliharaaa broiler.

Metode: Ternak yang digunakan dalam penelitian adalah day old chick (DOC) broiler Strain Ross Jumbo dengan rataan bobot badan 44,74 2,21 g/ekor. Perlakuan dibagi pada 3 mini closed house (LB: litter baru, LFPM: litter fermentasi pengeringan matahari, LFPA: litter fermentasi pengeringan dianginkan). Variabel meliputi kualitas litter (struktur pori, total bakteri, kadar air, daya serap) dan kualitas udara (karbon dioksida, amonia, konsentrasi hidrogen sulfida, dan debu total). Data kadar air dan daya serap litter didesain menggunakan rancangan acak lengkap (RAL) dan dianalisis ragam (SAS 9.0). Data total bakteri, struktur pori litter dan kualitas udara dianalisis secara deskriptif.

Hasil: Hasil penelitian menunjukkan bahwa penggunaan kembali litter yang telah didaur ulang tidak berpengaruh nyata terhadap kadar air dan daya serap litter. Luas pori-pori litter pada ketiga perlakuan menunjukkan hasil yang tidak berbeda. Litter yang difermentasi dan dikeringkan dengan sinar matahari menunjukkan penurunan total bakteri total (57,75\%), sedangkan litter yang difermentasi dan dianginkan (41\%). Kadar karbon dioksida, amonia, hidrogen sulfida, dan debu total pada semua perlakuan berada dalam kisaran normal.

Kesimpulan: Dapat disimpulkan bahwa penggunaan kembali litter yang telah didaur ulang tidak menurunkan kualitas litter dan kualitas udara dalam pemeliharaan ayam broiler.

Kata Kunci: Broiler; Litter baru; Fermentasi litter; Kualitas litter; Kualitas udara

\section{Abstract}

Objective: In general, farmers use litters from rice husks. However, along with the decline in paddy fields, rice husk is difficult to obtain and the price is expensive. One effort that can be done is to reuse the litter that has been used. The purpose of this study is to analyze the effect of recycling on the quality of litter and air in raising broiler.

Methods: Two hundred day old chick (DOC) males strain Ross jumbo with an average body weight of $44.74 \pm 2.21 \mathrm{~g}$ were used in this research. The research treatmens were divided into 3 mini closed-house cages (LB: new litter, LFPM: litter fermented and sun-dried, LFPA: litter fermented and aerated). The data of litter quality (pore structure, total bacteria, moisture content, and adsorption percentage) and air quality (carbon dioxide, ammonia, hydrogen sulfide concentration, and dust 
total) were collected. The data of moisture and adsorption percentage of litter were analyzed statistically using Completely Randomized Design (SAS 9.0). Total bacteria, litter pore structure and air quality were analyzed using descriptive analysis.

Results: The results showed that reusing litter did not influence the percentage of moisture and litter adsorption. The pore surface area of litter was not affected by the different treatments. The fermented and sun-dried litter showed a larger decreasing of total bacteria (57.75\%) compare to the fermented and aerated litter (41\%). Carbon dioxide, ammonia, hydrogen sulfide concentration, and dust total in all treatments were within the normal standard.

Conclusions: In conclusion, litter and air quality were not affected by reusing litter.

Keywords: Air quality; Broiler; Litter fermentation; Litter quality; New litter

\section{PENDAHULUAN}

Industri peternakan di Indonesia terus meningkat seiring dengan meningkatnya permintaan protein hewani baik daging maupun telur. Daging broiler merupakan penyumbang sebagian besar kebutuhan protein hewani di Indonesia. Konsumsi daging broiler mengalami peningkatan setiap tahunnya, pada tahun 2013 konsumsi daging broiler mencapai $12,75 \mathrm{~kg} / \mathrm{kapita}$ dan pada tahun 2017 meningkat menjadi 15,07 $\mathrm{kg} /$ kapita [1]. Perkembangan peternakan broiler ini juga berdampak pada meningkatnya jumlah limbah yang dihasilkan. Limbah peternakan selama ini menjadi perhatian yang serius karena dampak negatifnya terhadap lingkungan, kesehatan hewan dan keselamatan pekerja [2]. Salah satu jenis limbah yang dihasilkan yaitu litter bekas pemeliharaan.

Litter merupakan alas kandang yang berfungsi untuk menyerap air, menyerap ammonia, isolasi panas, dan meminimalkan ayam kontak langsung dengan lantai. Kualitas litter merupakan faktor penting dalam pemeliharaan broiler karena akan mempengaruhi kesehatan, performa, kesejahteraan broiler, dan produk yang dihasilkan. Litter yang basah dan lembab akan mengeluarkan bau busuk dan memicu timbulnya beberapa penyakit seperti coryza, coccidiosis, infeksi jamur dan parasit pada usus [3].

Peternak broiler di Indonesia pada umumnya menggunakan litter dari bahan sekam padi, hal ini karena sekam padi merupakan bahan yang sangat baik untuk menjaga kelembaban. Penggunaan sekam padi sebagai litter saat ini hanya digunakan untuk satu periode dan setelah itu diganti dengan litter yang baru. Peternak dengan jumlah yang banyak harus menyediakan sekam padi dalam jumlah yang banyak pula. Seiring dengan penurunan luas sawah yang dikonversikan menjadi lahan pemukiman, sekam padi menjadi sulit didapat dibeberapa daerah dan harganya mahal. Data BPS menunjukakan bahwa selama lima tahun terakhir luas lahan persawahan terus mengalami penurunan. Pada tahun 2014 tercatat luas lahan persawahan mencapai 8.111.593 Ha, menurun di tahun 2018 menjadi sekitar 7.105.145 Ha [1]. Di beberapa daerah sekam padi juga sulit didapat karena panen padi yang hanya satu tahun sekali. Perlu upaya untuk mengatasi kelangkaan sekam padi di masa mendatang. Salah satu upaya yang dapat dilakukan yaitu dengan melakukan daur ulang litter dengan cara fermentasi agar dapat digunakan kembali.

Fermentasi merupakan suatu proses penguraian atau perombakan bahan organik yang dilakukan dalam kondisi tertentu oleh mikroorganisme fermentatif. Komponen yang terkandung dalam litter bekas sebagai bahan fermentasi meliputi: Air, karbon (C), nitrogen $(\mathrm{N})$, dan bahan organik lainya [4]. Litter bekas juga mengandung banyak bakteri patogen seperti Enterobacteriaceae, Salmonella sp, Escherichia coli, Shigella sonnei, Campylobacter dan bakteri lainya [5]. Fermentasi litter dapat mengurangi total bakteri patogen pada hari ke-2 dan ke-4 pada suhu $62^{\circ} \mathrm{C}$, fermentasi juga dapat mengurangi berat, volume dan bau [6]. Litter yang telah difermentasi memiliki kadar air yang belum memenuhi syarat sebagai bahan litter yang baik. Kadar air litter setelah dilakukan fermentasi selama 12 hari berkisar antara $29-39^{\circ} \mathrm{C}$. Perlu dilakukan upaya untuk 
menurunkan kadar air tersebut. Penerapan daur ulang litter telah banyak dilakukan, akan tetapi masih sebatas untuk mengetahui pengaruhnya terhadap produktifitas. Dalam penelitian ini kami melakukan pengamatan kualitas litter dan udara yang merupakan faktor penting dalam pemeliharaan broiler. Tujuan dari penelitian ini adalah untuk mengkaji dan menganalisis pengaruh daur ulang terhadap kualitas litter dan kualitas udara dalam pemeliharaan ayam broiler. Diharapkan dengan penggunaan litter daur ulang dapat menggantikan penggunaan litter baru tanpa menurunkun kualitasnya dan tidak mempengaruhi kualitas udara dalam kandang.

\section{MATERI DAN METODE}

Sebanyak 120 ekor day old chick (DOC) jantan strain Ross Jumbo digunakan dalam penelitian ini, sekam padi baru dan litter bekas digunakan sebagai perlakuan serta pakan yang diberikan adalah BR 511 untuk fase starter dan BR 512 untuk fase finisher.

\section{Fermentasi litter}

Litter bekas yang diperoleh dari peternakan sekitar kemudian dibersihkan dari bulu dan benda asing lainya menggunakan alat pemisah manual. Selanjutnya litter diaerasi sampai dengan kadar air 50\% secara merata. Litter kemudian ditumpuk dan di tutup mengunakan plastik sehingga dalam keadaan anaerob. Diamkan selama 7 hari sampai proses fermentasi sempurna [7]. Pada hari terakhir litter dibongkar. Selanjutnya sebagian litter dianginkan selama 2 hari dan sebagian lagi dikeringkan dibawah sinar matahari selama 2 hari.

\section{Pemeliharaan}

Sebanyak 120 day old chick (DOC) broiler
Strain Ross Jumbo dipelihara selama 5 minggu yang dibagi dalam tiga unit kandang mini closed house dengan luas masing-masing $3 \times 3 \mathrm{~m}^{2}$. Satu kandang terdiri dari empat unit percobaan dengan luas $1 \times 1 \mathrm{~m}^{2}$, masing-masing unit percobaan terdiri dari 10 ekor ayam. Sebagai pemanas digunakan lampu pijar 60 watt. Pemberian pakan dan minum dilakukan ad libitum terkontrol dua kali sehari. Pakan yang digunakan pada fase strarter adalah BR511 dengan kandungan protein 22\% dan EM $2900 \mathrm{kkal} / \mathrm{kg}$, fase finisher diberikan pakan BR512 dengan kandungan protein minimal 20\% dan EM $3000 \mathrm{kkal} / \mathrm{kg}$.

\section{Peubah yang diamati}

Penelitian ini didesain mengunakan rancangan acak lengkap (RAL) dengan perlakuan litter baru (LB), litter fermentasi+pengeringan matahari (LFPM), dan litter fermentasi+dianginkan (LFPA) dengan 4 ulangan litter perlakuan yang diambil secara acak pada setiap perlakuan.

\section{Kualitas litter}

Pengambilan data kualitas litter meliputi kadar air, total bakteri, struktur pori-pori litter dan daya serap litter. Analisa proksimat dilakukan untuk mengetahui kadar air litter. Stuktur pori-pori litter diamati denga mikroskop elektron jenis Scanning Electron Microcope (SEM) dan luas permukaan pori diukur menggunakan software ImageJ [8]. Daya serap litter dihitung sesuai dengan Standar Nasional Indonesia [9]. Perhitungan jumlah bakteri dilakukan untuk mengetahui jumlah total bakteri dengan menggunakan metode total plate count [10].

\section{Kualitas udara}

Pengambilan data kualitas udara dilakukan di dalam kandang mini closed house pada awal minggu ke-5. Kualitas udara yang diamati meliputi kadar kadar amonia $\left(\mathrm{NH}_{3}\right)$,

Tabel 1. Rataan kadar air dan daya serap litter yang telah didaur ulang

\begin{tabular}{lccc}
\hline \multirow{2}{*}{ Parameter } & \multicolumn{3}{c}{ Perlakuan } \\
\cline { 2 - 4 } & LB & LFPM & LFPA \\
\hline Kadar air (\%) & $9,96 \pm 1,17$ & $9,51 \pm 1,21$ & $9,61 \pm 1,56$ \\
Daya serap (\%) & $166,75 \pm 9,46$ & $167,50 \pm 8,89$ & $163,50 \pm 8,43$ \\
\hline
\end{tabular}

LB, litter baru; LFPM, litter fermentasi dan pengeringan matahari; LFPA, litter fermentasi dan dianginkan. 
karbon dioksida $\left(\mathrm{CO}_{2}\right)$, hidrogen sulfida $\left(\mathrm{H}_{2} \mathrm{~S}\right)$ dan debu total.

Pengujian amonia diukur menggunakan spektrophotometer dengan panjang gelombang $630 \mathrm{~nm}$, Pengujian $\mathrm{CO}_{2}$ dilakukan menggunakan alat ukur komposisi gas otomatis. Pengujian $\mathrm{H}_{2} \mathrm{~S}$ dilakukan dengan mengunakan spektrofotometer pada panjang gelombang $670 \mathrm{~nm}$ [11] dan pengujian debu total dilakukan dengan cara mengambil debu di udara mengunakan low volume dust sample (LVS). Kadar debu total yang diukur ditentukan secara gravimetri [12].

\section{Analisis data}

Data kualitas litter (daya serap dan kadar air litter) dianalisis mengunakan analisis ragam (analysis of variance/ANOVA). Jika menunjukkan perbedaan nyata dilanjutkan dengan uji tukey [13]. Analisis data mengunakan program software SAS 9.4. Data total bakteri, struktur pori-pori, dan kualitas udara yang diperoleh di analisa secara deskriptif.

\section{HASIL}

\section{Struktur pori-pori litter}

Pengamatan struktur pori-pori litter dilakukan untuk mengetahui penampakan serta luas permukaan dari pori-pori litter yang telah didaur ulang. Hasil pengamatan menggunakan mikroskop SEM ditunjukkan pada Gambar 1. Berdasarkan hasil pengamatan SEM dengan perbesaran 2000x dan dilanjutkan dengan pengukuran menggunakan software ImageJ dapat diketahui bahwa luas permukaan pori-pori litter baru 355,58 $\mathrm{nm} 2$, litter fermentasi pengeringan matahari $362,53 \mathrm{~nm} 2$ dan litter fermentasi dianginkan 365,41 nm2. Luas permukaan ketiga perlakuan relatif sama dan struktur pori-pori litter juga tidak tertutup. Pada permukaan litter yang difermentasi terlihat adanya proses degradasi yang disebabkan oleh aktivitas bakteri pengurai.

\section{Total bakteri}

Salah satu tujuan daur ulang menggunakan metode fermentasi adalah untuk mengurangi total bakteri yang ada pada litter bekas, sehingga tidak menimbulkan efek negatif pada pemeliharaan selanjutnya. Fermentasi merupakan suatu proses penguraian bahan organik yang dilakukan dalam kondisi tertentu oleh mikroorganisme fermentatif. Berdasarkan penelitian diperoleh data rataan total bakteri pada litter yang disajikan pada Gambar 2. Berdasarkan hasil penelitian dapat diketahui bahwa total bakteri pada litter yang telah didaur ulang (LFPM dan LFPA) lebih rendah dibandingkan dengan litter bekas. Proses fermentasi litter dan pengeringan matahari dapat menurunkan total bakteri sampai dengan $57.75 \%$. Fermentasi litter dan pengeringan dengan dianginkan dapat menurunkan total bakteri litter sampai dengan $41 \%$.

\section{Kadar air dan daya serap}

Kadar air yang rendah merupakan salah satu syarat yang harus dipenuhi sebagai bahan litter yang baik. Kadar air berpengaruh terhadap kemampuan menyerap suatu bahan. Berdasarkan hasil penelitian diperoleh data rata-rata kadar air dan daya serap litter perlakuan disajikan pada Tabel 1.

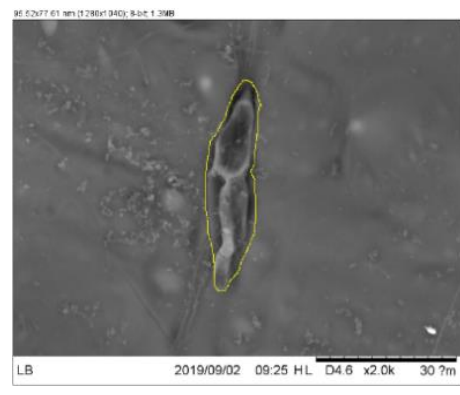

a

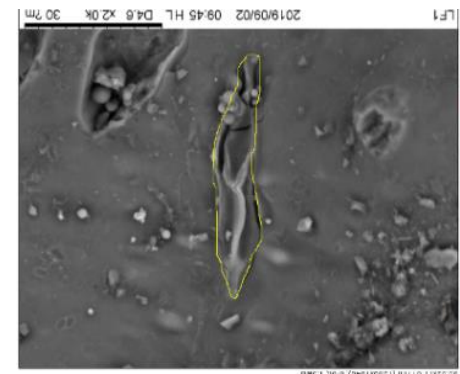

b

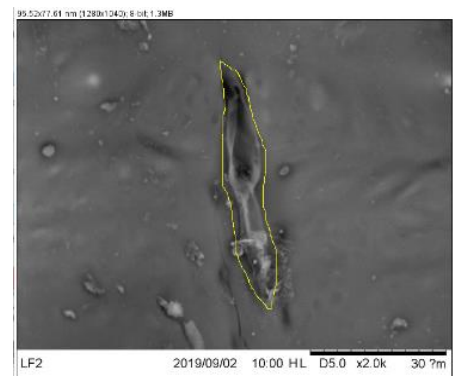

C

Gambar 1. Struktur pori-pori litter dengan 2000x pembesaran. a, litter baru; b, litter fermentasi + dikeringkan; c, fermentasi + dianginkan 
Berdasarkan hasil analisis statistik kadar air litter dan daya serap menunjukkan tidak ada perbedaan nyata antara litter baru dan litter daur ulang. Rata-rata kadar air litter berkisar antara $9,51 \pm 1,21 \%-9,96 \pm 1,17 \%$. Nilai daya serap litter berkisar antaran $163,50 \pm 8,43-167,50 \pm 8,89 \%$.

\section{Amonia $\left(\mathrm{NH}_{3}\right)$}

Emisi amonia dari usaha peternakan selama ini menjadi perhatian yang serius karena dampak negatifnya terhadap lingkungan, kesehatan hewan dan keselamatan orang yang bekerja di peternakan [2]. Kadar amonia yang tinggi dalam kandang akan berpengaruh buruk terhadap performa, efisiensi pakan dan kesejahteraan hewan [14]. Berdasarkan hasil penelitian, kadar ammonia tertinggi pada perlakuan LFPA sebesar 5,28 ppm, selanjutnya LFPM 2,24 ppm dan terendah pada LB 1,49 ppm.

\section{Hidrogen sulfida $\left(\mathrm{H}_{2} \mathrm{~S}\right)$}

Hidrogen sulfida merupakan salah satu senyawa sulfur yang mudah menguap, sangat berbau, tidak berwarna, dan larut dalam air. Gas ini dihasilkan dari proses penguraian kotoran yang didalamnya terkandung sulfur oleh bakteri sulfat [15]. Gas tersebut toksik bagi manusia dan hewan serta dapat meningkatkan kerentanan penyakit dan mengganggu efisiensi aktivitas para pekerja [16]. Hasil analisis $\mathrm{H}_{2} \mathrm{~S}$ didalam kandang broiler yang dipelihara menggunakan litter daur ulang (Tabel 2) menunjukkan bahwa kadar $\mathrm{H}_{2} \mathrm{~S}$ antar perlakuan relative sama. Pada perlakuan LB kadar $\mathrm{H}_{2} \mathrm{~S}$ 0,0032 ppm, LFPM 0,0039 ppm, dan LFPA 0,0032 ppm.

\section{Karbon dioksida $\left(\mathrm{CO}_{2}\right)$}

$\mathrm{CO}_{2}$ merupakan gas tidak bewarna dan tidak berbau yang dihasilkan dari proses respirasi ternak sebagai hasil akhir dari proses metabolisme dan kotoran. $\mathrm{CO}_{2}$ menjadi salah satu indicator dalam menentukan kualitas udara di lingkungan peternakan [17]. Hasil analisis kualitas udara menunjukkan terjadi peningkatan kadar $\mathrm{CO}_{2}$ pada kandang yang menggunakan litter daur ulang. Pada perlakuan LB sebesar 0,026 ppm, LFPM 0,039 ppm, dan LFPA sebesar 0,042 ppm.

\section{Debu total}

Debu merupakan partikel kecil yang berukuran kurang dari $100 \mu \mathrm{m}$. Debu pada peternakan berasal dari litter, pakan, bulu yang rusak, dan kotoran [18]. Hasil analisis debu total didalam kandang broiler yang dipelihara menggunakan litter daur ulang (Tabel 2) menunjukkan bahwa kadar debu paling tinggi pada perlakuan LB 9,30 $\mathrm{mg} / \mathrm{Nm}^{3}$, selanjutnya LFPM $4,65 \mathrm{mg} / \mathrm{Nm}^{3}$, dan terendah pada LFPA $1,21 \mathrm{mg} / \mathrm{Nm}^{3}$.

\section{PEMBAHASAN}

\section{Struktur pori-pori litter}

Struktur pori-pori litter dan juga luas permukaan litter dari ketiga perlakuan relative sama, ini menandakan bahwa proses fermentasi dan juga perlakuan pengeringan tidak merusak dan menutup struktur pori-pori litter. Hal ini didukung dengan hasil uji daya serap serta kadar air yang menunjukkan tidak berbeda nyata antar perlakuan, sehingga tidak mempengaruhi kemampuan adsorbsi. Adsorbsi merupakan fenomena fisik yang terjadi saat molekul-molekul gas atau cair mengalami

Tabel 2. Konsentrasi $\mathrm{NH}_{3}, \mathrm{H}_{2} \mathrm{~S}, \mathrm{CO}_{2}$ dan debu total di dalam kandang pemeliharaan broiler

\begin{tabular}{lcccc}
\hline \multirow{2}{*}{ Parameter } & \multicolumn{3}{c}{ Perlakuan } & \multirow{2}{*}{ Standar } \\
\cline { 2 - 4 } & LB & LFPM & LFPA & $<25$ \\
\cline { 2 - 4 } $\mathrm{NH}_{3}(\mathrm{ppm})$ & 1,49 & 2,24 & 5,28 & $<0.02$ \\
$\mathrm{H}_{2} \mathrm{~S}(\mathrm{ppm})$ & 0,0032 & 0,0039 & 0,0032 & $<3000$ \\
$\mathrm{CO}_{2}(\mathrm{ppm})$ & 0,026 & 0,039 & 0,042 & $<230$ \\
Debu total $\left(\mathrm{mg} / \mathrm{Nm}^{3}\right)$ & 9,30 & 4,65 & 1,21 & \\
\hline
\end{tabular}

LB, litter baru; LFPM, litter fermentasi dan pengeringan matahari; LFPA, litter fermentasi dan dianginkan. 
kontak dengan suatu permukaan padatan dan sebagian dari molekul-molekul mengembun pada permukaan padatan tersebut [19]. Pada gambar SEM dapat dilihat bahwa struktur permukaan litter daur ulang mengalami degradasi. Hal ini disebabkan karena terjadi proses perombakan bahan organik yang dilakukan oleh bakteri fermentative. Pada suhu $>50^{\circ} \mathrm{C}$ dengan kelembapan $40-60 \%$ memungkinkan bakteri fermentative untuk mengurai bahan organik menjadi partikel yang lebih sederhana [20].

\section{Total bakteri}

Berdasarkan hasil penelitian dapat diketahui bahwa total bakteri pada litter yang telah didaur ulang (LFPM dan LFPA) lebih rendah dibandingkan dengan litter bekas. Pada litter bekas total bakteri mencapai 8,9×10 $\mathrm{cfu} / \mathrm{g}$, setelah dilakukan fermentasi dan dianginkan total bakteri menurun hingga $5,25 \times 10^{6} \mathrm{cfu} / \mathrm{g}$, terjadi penurunan $41 \%$. Pada fermentasi dan pengeringan dengan bantuan sinar matahari menurun sampai $3,76 \times 10^{6}$ $\mathrm{cfu} / \mathrm{g}$ atau $57,75 \%$. Penurunan total bakteri terjadi karena proses fermentasi yang menghasilkan panas. Kondisi panas ini yang akan membunuh sebagian bakteri yang ada pada litter. Fermentasi litter yang ditutup dengan plastik selama satu minggu dapat meningkatkan suhu litter lebih dari $50^{\circ} \mathrm{C}$ dan selama proses fermentasi sangat efektif dalam mengeliminasi jumlah bakteri coliform [21]. Penurunan jumlah bakteri pada perlakuan daur ulang juga karena terbentuknya amonia dari proses fermentasi yang akan membunuh bakteri. Proses fermentasi tertutup akan menghasilkan konsentrasi amonia yang lebih tinggi pada hari 1-7. Amonia akan mempengaruhi proses metabolisme sel, glikolisis dan siklus asam sitrat pada bakteri. Amonia juga menyebabkan perubahan $\mathrm{pH}$ intraseluler, yang mempengaruhi proton gradien dan menghambat endositosis dan eksositosis, sehingga menyebabkan kematian sel [22].

\section{Kadar air dan daya serap}

Berdasarkan hasil analisis statistik kadar air litter dan daya serap menunjukkan tidak ada perbedaan nyata antara litter baru dan litter daur ulang. Nilai kadar air dalam penelitian ini masih sesuai standar kadar air litter yang baik yaitu kurang dari $25 \%$. Kadar air litter yang baik untuk digunakan sebagai alas kandang apabila kurang dari 25\% [23]. Kadar air dalam litter erat hubunganya dengan kemampuan litter dalam melakukan penyerapan. Semakin rendah kadar air dalam litter maka kemampuan menyerapnya akan semakin tinggi, begitu juga sebaliknya. Beberapa faktor yang mempengaruhi kadar air litter diantaranya asal bahan, jenis bahan serta pengolahan bahan sebelum digunakan sebagai litter. Kandungan air dalam suatu bahan berpengaruh pada kemampuan penyerapanya. Bahan litter yang baik bilamana memiliki daya serap tinggi. Semakin tinggi daya serap litter maka kemampuan untuk menyerap kelembapan juga akan semakin baik [24].

\section{Amonia ( $\left.\mathrm{NH}_{3}\right)$}

Tingginya kadar ammonia pada LFPA dibandingkan dengan perlakuan lainya disebabkan karena total bakteri pada

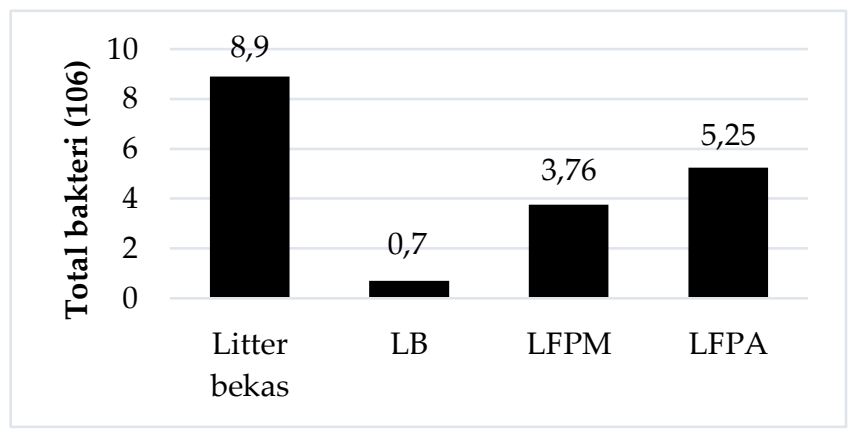

Gambar 2. Rataan total bakteri litter. LB, litter baru; LFPM, litter fermentasi dan pengeringan matahari; LFPA, litter fermentasi dan dianginkan 
perlakuan LFPA yang juga lebih banyak. Bakteri berperan dalam pembentukan amonia melaluai proses dekomposisi. Semakin banyak total bakteri dalam litter maka kemampuan untuk mendekomposisi akan semakin tinggi. Amonia dihasilkan dari proses dekomposisi kotoran oleh bakteri penggurai khususnya bakteri eurolitik. Bakteri eurolitik menghasilkan enzim urease yang selanjutnya digunakan untuk memecah nitrogen dalam kotoran menjadi amonia [25]. Hasil analisis kualitas udara (Tabel 2) menunjukkan bahwa kadar amonia dari penelitian ini masih dalam batas ambang normal. Ambang batas amonia dalam pemeliharaan broiler adalah $25 \mathrm{ppm}$. Kadar ammonia diatas ambang batas akan menyebabkan iritasi mata, gangguan saluran pernapasan, dan efek negative lainya [26].

\section{Hidrogen sulfida $\left(\mathrm{H}_{2} \mathrm{~S}\right)$}

Hasil analisis $\mathrm{H}_{2} \mathrm{~S}$ menunjukkan bahwa kadar $\mathrm{H}_{2} \mathrm{~S}$ antar perlakuan relative sama. Hal ini disebabkan karena konsumsi pakan serta kandungan nutrisi pakan yang diberikan sama baik kandungan energi maupun proteinya. Ekskreta yang masih mengandung sisa-sisa protein akan diurai oleh bakteri pengurai menjadi asam-asam amino. Asam amino terutama sistin dan methionine yang mengandung sulfur ini kemudian kembali didegradasi menjadi senyawa yang sederhana oleh bakteri sulfat sehingga terbetuk hidrogen sulfide. Kadar $\mathrm{H}_{2} \mathrm{~S}$ dalam penelitian ini tergolong rendah dan masih dalam ambang batas normal, ambang batas $\mathrm{H}_{2} \mathrm{~S}$ untuk ayam adalah 0,02 ppm [27].

\section{Karbon dioksida $\left(\mathrm{CO}_{2}\right)$}

Meningkatnya kadar $\mathrm{CO}_{2}$ pada perlakuan LFPM dan LFPA disebabkan karena jumlah total bakteri yang lebih banyak. Selain dihasilkan dari proses metabolism ayam, $\mathrm{CO}_{2}$ juga dihasilkan dari proses metabolism bakteri yang ada didalam kandang. Kadar $\mathrm{CO}_{2}$ dalam penelitian ini tergolong rendah dan masih dalam batas ambang normal. Ambang batas $\mathrm{CO}_{2}$ di lingkungan peternakan yaitu 3000 ppm. Konsentrasi $\mathrm{CO}_{2}$ di udara yang terlalu tinggi akan menyebabkan gangguan sirkulasi dan menurunnya nafsu makan. Pada industri peternakan kadar $\mathrm{CO}_{2}$ dipengaruhi oleh bobot badan dan ventilasi kandang [28].

\section{Debu total}

Tingginya kadar debu pada perlakuan LB disebabkan karena aktifitas ayam yang lebih aktif dibandingkan dengan perlakuan yang lain. Kadar $\mathrm{NH} 3$ dan $\mathrm{CO}_{2}$ pada perlakuan LB yang lebih rendah juga menjadi salah satu factor yang menyebabkan ternak lebih aktif bergerak. Partikel debu di udara salah satunya disebabkan karena adanya gesekan antara ayam dengan litter secara terus menerus [29]. Hasil pengamatan tingkah laku selama penelitian menunjukkan bahwa pada perlakuan LFPA dengan kadar $\mathrm{NH}_{3}$ dan $\mathrm{CO}_{2}$ yang lebih tinggi ayam cenderung lebih pasif sehingga debu total di udara lebih sedikit. Debu total dalam penelitian ini masih jauh dibawah ambang batas normal, sehingga tidak sampai mengganggu kesehatan dan performa ternak. Standar baku mutu PP RI No.41 Tahun 1999 yaitu sebesar $230 \mathrm{mg} / \mathrm{Nm}^{3}$.

\section{KESIMPULAN}

Litter bekas yang telah diolah dengan fermentasi dapat digunakan kembali sebagai litter broiler dengan kualitas yang sama dengan litter baru.

\section{KONFLIK KEPENTINGAN}

Penulis menyatakan tidak ada konflik kepentingan dengan pihak manapun terkait materi yang ditulis dalam naskah ini.

\section{UCAPAN TERIMA KASIH}

Ucapan terima kasih penulis sampaikan kepada LPDP (lembaga pengelola dana pendidikan) yang telah membiayai seluruh biaya kuliah serta biaya penelitian sehingga studi master penulis dapat berjalan lancar.

\section{DAFTAR PUSTAKA}

1. BPS. Badan pusat statistik tabel dinamis [internet]. Badan Pusat Statistik; 2018 
[cited 2019 Feb 23] Available from. https://www.bps.go.id/linkTableDinamis/ view/id/895.

2. Atapattu, N. S. B. M., L. G. E. Lakmal, and P.W.A. Perera. 2017. Effects of two litter amendments on air NH3 levels in broiler closed-houses. Asian-Austral. J. Anim. Sci. 30:1500-1506. doi:10.5713/ajas.16.0873.

3. Monira, K. N., M. A. Islam, M. J. Alam, and M. A. Wahid. 2003. Effect of litter materials on broiler performance and evaluation of manureal value of used litter in late autumn. Anim. Sci. 16:555-557. doi:10.5713/ajas.2003.555.

4. Kelleher, B. P., J. J. Leahy, A. M. Henihan, T. F. O'dwyer, D. Sutton, and M. J. Leahy. 2002. Advances in poultry litter disposal technology-a review. Bioresour. Technol. 83:27-36. doi:10.1016/S0960-8524(01)00133-X.

5. Cook, A., J. Odumeru, S. Lee, and F. Pollari. 2012. Enumeration and subtypes on retail chicken breasts with and without skin. J. Food Prot. 75:34-40. doi:10.4315/0362-028X.

6. Kwak, W. S. 2005. Effect of processing time on enteric bacteria survival and on temperature and chemical composition of broiler poultry litter processed by two methods. Bioresour. Tehnol. 9:1529-1536. doi:10.1016/j.biortech. 2004.12.018.

7. Muniz, E., D. Mesa, and A. M. Souza. 2013. Presence of Salmonella spp. in reused broiler litter. Rev. Colomb. Cienc. Pec. 2:12-17.

8. Desiati, R. D., E. Sugiarti, and S. Ramadhany.2018. Analisa ukuran partikel serbuk komposit nicral dengan penambahan reaktif elemen untuk aplikasi lapisan tahan panas. Metalurgi. 1:27-34. doi:10.14203/metalurgi.v33i1.358.

9. Standar Nasional Indonesia. 1996. Bata beton (Paving block). Badan Standardisasi Nasional, Bandung.

10. Pelczar, M. J. and E. C. S. Chan. 2009. Dasar-dasar mikrobiologi. Jilid 2. Hadioetomo dkk, penerjemah. Terjemahan dari: Elements of Microbiology. UI Press, Jakarta.

11. Standar Nasional Indonesia. 2005. SNI No 19-7117.7 tentang emisi gas buang. Sumber tidak bergerak. Bagian 7 cara uji Hydrogen
Sulfida (H2S) dengan metode biru metilen menggunakan spektrofotometer. Badan Standardisasi Nasional, Jakarta.

12. Standar Nasional Indonesia. 2004. SNI no SNI 16-7058 tentang pengukuran kadar debu total di udara tempat kerja, Badan Standardisasi Nasional, Jakarta.

13. Mattjik, A. A. and Sumertajaya. 2006. Perancangan percobaan. Ed ke-2. IPB Press, Bogor.

14. Miles, D. M., S. L. Branton, and B. D. Lott. 2004. Atmospheric ammonia is detrimental to the performance of modern commercial broilers. Poult. Sci. 83:650-1654. doi:10.1093/ps/83.10.1650.

15. Saksrithai, K. and A. J. King. 2018. Controlling hydrogen sulfide emissions during poultry productions. J. Anim. Feed Sci. 3:1-14. doi:10.21767/2572-5459.100040.

16. Martins, R. S., M. J. Hötzel, and R. Poletto. 2014. Influence of in-house composting of reused litter on litter quality, ammonia volatilisation and incidence of broiler foot pad dermatitis. Br. Poult. 54:669-676 doi:10.1080/00071668. 2013.838747.

17. Ni, J. Q., A. J. Heber, S. M. Hanni, T. T. Lim, and C. A. Diehl. 2010. Characteristics of ammonia and carbon dioxide releases from layer hen manure. Br. Poult. 51:326-334. doi:10.1080/00071668.2010.

18. Homidan, A. A., J. F. Robertsonz, and A. M. Petchey. 2003. Review of the effect of ammonia and dust concentrations on broiler performance. World Poultry Sci. J. 59:340-349. doi:10.1079/WPS20030021.

19. Wijayanti, H. 2009. Karbon aktif dari sekam padi: pembuatan dan kapasitasnya untuk adsorpsi larutan asam asetat. Info Tehnologi. 10:61-67.

20. Costa, M. S. S. M., L. A. M. Costa, A. Pela, A. C. J. Silva, L. D. Decarli, and U. F. Matter. 2006. Desempenho de quatro sistemas para compostagem de carcaça de aves. Braz. J. Poultry Sci. 10:692-698. doi:10.1590/S1415-43662006000300023.

21. Macklin, K. S., J. B. Hess, S. F. Bilgili, and R. A. Norton. 2006. Effects of in-house composting of litter on bacterial levels. J. Appl. Poult. Res. 15:531-537. doi:10.1093/japr/15.4.531.

22. Schneider M, Marison I, Stockar U. 1996. The importance of ammonia in 
mammalian cell culture. J. Biotechnol. 46:161-185.

23. Saravanan, K. 2018. A Study on the concept of reutilization of litter in broiler poultry farms. Int. J. Eng. Res. Gen. Sci. 6:30-34.

24. Lopes, M., V. F. B. Roll, F. L. Leite, M. A. D. Prá, E. G. Xavier, T. Heres, and B. S. Valente. 2013. Quicklime treatment and stirring of different poultry litter substrates for reducing pathogenic bacteria counts. Poult. Sci. 9:638-644. doi:10.3382/ps.2012-02700.

25. Marin, I. F. F., J. A. O. Saraz, C. F. Souza, and M. F. A. Vieira. 2015. Evaluation of the fertilizer and contamination potential of different broiler litter types subjected to various use cycles. Rev. Fac. Nac. Agron. Medellin. 68:63-74 doi:10.15446/rfnam. v68n2.50967.

26. Sousa, F. C., M. Barbari, F. Baptista, C. F. Souza1, A. O. Saraz, D. J. R. Coelho, and A. L. Silva. 2018. Diagnosis of air quality in broilers production facilities in hot climates. Agron. Res. 16:582-592. doi:10.15159/AR.18.070.

27. Guarrasi, J., C. Trask, and S. Kirychuk. 2015. A sistematic review of occupational exposure to hydrogen sulfide in livestock operational. J. Agromedicine. 20:225-236. doi:10.1080/1059924X.2015.1009667.

28. Skora, J., K. Matusiak, P. Wojewódzki, A. Nowak, M. Sulyok, A. Ligocka, Okrasa, M. A. Hermann, and B. Gutarowska. 2016. Evaluation of microbiological and chemical contaminants in poultry farms. Int. J. Environ. Res. Public Health. 13:192-207. doi:10.3390/ijerph13020192.

29. Ulupi, N., Salundik, D. Margisuci, R. Hidayatun, and B. Sugiarto. 2015. Growth performance and production of ammonia and hydrogen sulfide in excreta of broiler chickens fed basil (Ocimum basilicum) flour in feed. Int. J. Poult. Sci. 14:112-116. doi:10.3923/ijps.2015.112.116. 